\title{
Antimonies of Crude Oil Production in the Niger Delta: Reflection on Ahmed Yerima's Trilogy
}

\author{
Norbert Oyibo Eze ${ }^{1}$, Ndubuisi Nnanna² \& Emeka Aniago 3 \\ ${ }^{1}$ Senior lecturer, Dept. of Theatre \& Film Studies, University of Nigeria, Nsukka, Nigeria \\ ${ }^{2}$ Lecturer, Dept. of Theatre \& Film Studies, University of Nigeria, Nsukka, Nigeria \\ ${ }^{3}$ Senior lecturer, Dept. of Theatre \& Film Studies, University of Nigeria, Nsukka, Nigeria \\ Email: emekaaniago@gmail.com ORCID: 0000-0003-3194-1463.
}

\begin{abstract}
We learn from history that some consequences of abysmal government policies and dysfunctional tactics include socio-economic retrogression, increased deprivation ideology, victimhood, rebellion, war and revolution; and theorists have provided several plausible contextualizations for elucidation. One of such conceptualizations is Ted Robert Gurr's theory of relative deprivation, which can be applied to illuminate sufficiently how discontent enacted in Ahmed Yerima's trilogy can lead to aggressive responses. Thus, through an interpretive approach, we shall look at how Yerima portrays creatively in his trilogy - Hard Ground, Little Drops, and Ipomu why a show of force, divide and rule, carrot and stick tactics by successive Nigerian governments have exacerbated grief, restiveness and rebellion in Niger Delta because of unwholesome oil exploitation and ineffectual corporate social responsibility approaches. In the end, this study proposes that Niger Delta oil exploitation related discontent will fester and linger if functional inclusiveness and proportional infrastructural development are not deployed progressively.
\end{abstract}

\section{Keywords}

Corruption, crude oil, Niger Delta, rebellion, relative deprivation

\section{Introduction}

The Niger Delta came into limelight for the first time in global history during the Trans-Atlantic slave trade, when it served as terminal for the evacuation of slaves to America, Europe and the West Indies. Following the scrambling for Africa and the emergence of commodity trade, the region became the hub of commercial activities. According to Kenneth Dike, the Niger Delta described by Winwood Reade as 'the Venice of West Africa', had by 1830, became, "the greatest single trading area in West Africa" (1974: 14). The navigability of its deep creeks and waterways made it a centre of attraction for the European merchants during the afore-mentioned period. Again, the discovery of oil in the area in 1956 gives the Niger Delta a prime position in modern Nigeria economic history. The 'black gold' which is the major source of the country's revenue is essentially the prime basis for Nigeria's integration into the global market. The world's high-tech 
economies are dependent on energy of which oil is the major supplier and the demand for oil worldwide has led to mutual suspicion among the world economic powers.

Nigeria is a heavily oil-dependent federation and as such the struggle to have access and the control of oil is very intense, thus Oyeh Oko Ota observes that "oil is the dominant motif, defining metaphor, and most importantly, site of contestation and oppositionality in postcolonial Niger Delta" (2017: 356). There is an intricate power play between the government and the people, and between the multinationals and the people as well as among the people themselves. As a result of the poor management of the resource and more significantly, the undue pressure put on the people's means of livelihood by oil spillage, gas flaring and effluents from refineries, all kinds of crises erupt in the area daily, including the struggle for resource control by the Niger Deltans who feel alienated from the product of their soil. Indeed, the unintelligent use of oil proceeds and the capitalist spirit of the oil extracting companies created all kinds of antimonies which have continued to engage political scientists, economists, sociologists, environmentalists, human rights activists and creative thinkers and writers. In his assessment of the persisting socio-economic retrogression in Nigeria, Chinua Achebe notes that the "trouble with Nigeria is simply and squarely a failure of leadership" (1983: 22). Furthering, Achebe contends that "there is nothing wrong with the Nigeria's land or climate or water or air" rather "Nigeria's problem is the unwillingness or inability of its leaders to rise to the responsibility, to the challenge of personal example which is the hallmark of true leadership" (1983: 22). In what clearly is an affirmation of Achebe's position Michael Ogbeidi in his article entitled 'Political Leadership and Corruption in Nigeria Since 1960: A Socio-economic Analysis', observes that Nigeria's poor developmental strides and continuing restiveness is fundamentally the problem of bad and retrogressive leadership. He laments that:

It is a paradox that Nigeria, the world's eighth largest exporter of crude oil, a country endowed with many resources, still has more than 70 percent of its population living below the poverty line as a result of corruption and economic mismanagement. Pathetically, the logic of the Nigerian political leadership class has been that of self-service as some of the leaders are mired in the pursuit of selfish and personal goals at the expense of broader national interests. (Ogbeidi, 2012: 3)

Ogbeidi's contribution indicates that the quest for progress and peaceful co-existence in Nigeria has continued to remain a dream because of unpatriotic disposition and actions of leaders. Furthering, he reveals poignantly the human factors and variables behind Nigeria's problems revolves around corruption, nepotism, mediocrity and greed because "unfortunately, the political class saddled with the responsibility of directing the affairs of the country have been the major culprit in perpetrating this act" (Ogbeidi, 2012: 3). He notes that "regrettably, since independence a notable surviving legacy of the successive political leadership both civilian and military that has managed the affairs of the country at different times has been the institutionalization of corruption in all agencies of the public service" (Ogbeidi, 2012: 3). In his contribution which affirms both Achebe's and Ogbeidi's contributions, Emeka Aniago observes that "when leadership is deemed to have failed, people concerned usually begin to ask questions and evidently in Nigeria's case; corruption is majorly viewed as the cancer" (2017: 26). The meaning of expression corruption which according to Dirk Tänzler et al (2012: 3) "changes over time and from place to place" is within the context of this analysis defined as deliberate intent by a person or organization entrusted with a position of authority, to dishonestly or fraudulently abuse such power to acquire 
illicit benefit or private gain as defined by subsisting laws of a concerned country. Thus, corruption from highest level of government is blamed for the victimhood disposition of the Niger Deltans.

In this study, attempt will be made to examine how Ahmed Yerima's trilogy comprising Hard Ground, Little Drops and Ipomu dramatize the nightmare that oil extraction and refining have bought into existence in the Niger Delta. The expectation is that oil extraction and refining in the Niger Delta will empower the people economically, socially and even politically but this is not the case as "the dominant class ideology and its interest is elaborated" and promoted by the capitalists as "the prevailing architecture of power" (Ibeanu, 2008:7). This paper seeks to interrogate Yerima's trilogy using the antimonies of oil production in the Niger Delta as articulated by Okechukwu Ibeanu in his inaugural lecture entitled, Affluence and Affliction: The Niger Delta as a Critique of Political Science in Nigeria. In this lecture, Ibeanu refers to the Niger Delta crude oil as "the devil's excrement" (2008: 16). Espousing, he captures the antimonies, ironies and paradoxes of oil extraction in the Niger Delta in the following words:

The devil's excrement has been a source of wealth and poverty, security and insecurity, and development and underdevelopment in equal measure. Ironically those from whose land it is taken are always on the negative side of its inherent paradoxes-they are poor, insecure and underdeveloped [...]. Surely only something associated with the devil, particularly the waste from the devil's entrails can be so inherently contradictory and pathological in character. At one and the same time, it will pay for the next meal of millions of Nigerians and it will also orphan hundreds of Nigerian children who will lose their parents in the inferno taking place in the Niger Delta presently. Many Nigerian leaders will smile tomorrow because of their access to the devil's excreta, while millions of other ordinary Nigerians in creeks of the Niger Delta will drown in it and have their livelihoods wiped out by oil spillage and reckless discharge of effluents of crude oil mining and refining into a fragile ecosystem. (Ibeanu, 2008: 16 - 17).

The antimonies articulated above are consistent with the Marxist perception of life as lived in a capitalist system where social formation exists in binary terms. The contradictions of oil production in the Niger Delta appear in form of affluence versus affliction; development against underdevelopment, and national security, versus insecurity of the Niger Delta. The horrible imageries projected by these attributions metaphorically represent a case of persistent and consistent dichotomy between the "rich and poor people" (Enekwe, 1900: 155), or to use Ibeanu's parlance, "islands of affluence in a sea of deprivation" (2008: 29).

Surely it is this perceived ongoing and relative deprivation of the Niger Deltan that seems to underlie and generate discontent, which create potential for collective aggressive restiveness and violence. According to Ted Robert Gurr, relative deprivation generates a form of frustration that can lead to aggressive responses. Gurr explains that relative deprivation "is defined as actors' perception of discrepancy between their value expectations and their value capabilities" (1970: 24). Therefore, it explains the needs and desires "to which people believe they are rightfully entitled" and that which "they think they are capable of getting and keeping" (Gurr, 1970: 24). However, deprivation is not strictly the lack of what individual's wants or needs because not all wants and needs are rationally tenable, but the wants and needs which are within such individual's rights, and those which they rationally and rightly ought to have. In his conceptualization, Gurr explains that "the primary source of the human capacity for violence appears to be the frustrationaggression mechanism" even though every form or all incidences of "frustration does not 
necessarily lead to violence, and violence for some men is motivated by expectations of gain" (1970: 36). Buttressing further, Gurr notes:

The anger induced by frustration, however, is a motivating force that disposes men to aggression, irrespective of its instrumentalities. If frustrations are sufficiently prolonged or sharply felt, aggression is quite likely, if not certain to occur. To conclude that the relationship is not relevant to individual or collective violence is akin to the assertion that the law of gravitation is irrelevant to the theory of flight because not everything that goes up falls back to earth in accord with the basic gravitational principle. The frustration-aggression mechanism is in this sense analogous to the law of gravity: men who are frustrated have an innate disposition to do violence to its source in proportion to the intensity of their frustrations. (1970: 36 - 37)

The point we take from Burr's conceptualization is that frustration can propel aggressive response; hence Yerima paints pictures in his trilogy exhibiting the responses which are blamed on prolonged frustration and deep sense of deprivation.

\section{Ahmed Yerima's trilogy: Synopsis and perspectives}

Ahmed Yerima's Hard Ground, Little Drops and Ipomu variously paint disheartening pictures of how what is supposed to be a source of affluence, breeds affliction and turns a once happy fishing and farming area into a madhouse of social discontent and death. Hard Ground portrays the state of mistrust and uncertainties existing among family members due to the oil politics and its attendant crisis. In the text, Nimi has just been rescued from being killed by the government joint task force which raided their camp, killing scores of the militants for kidnapping four expatriate oil workers. Whereas Nimi is convinced that it was his uncle, Fr. Kingsley who informed the police of the deed, Inyingifaa his maternal uncle used to bribe his rescue, informed him and his parents, Mama and Baba that the leader of the group, Don has placed a death sentence on Nimi because everyone fingered him as the one who released the information that led to the crackdown. This vexes Nimi and puts him in a pensive mood. While Mama gets upset about Nimi's involvement in militant activities and insists that he does not return to the camp again. She remembers the untold pain which the Don had caused her family by ordering the killing of her brother Soibifaa in the past. The irony is that Baba, whom Mama looks down on in the house and describes with every epithet of poverty and weakness, is actually the Don who is so terribly feared. This of course is made apparent in the last segment of the play where Nimi who has prepared to confront the Don for ordering the killing of his wife Pikibo and her unborn child engages the Don in a scuffle immediately he steps into the house and slits his throat in one stroke. The deed done, Nimi shouts, "I have killed the devil," and Mama, requests to see the face of the man that has caused her so much pain. In a moment, Nimi slowly removes the scarf which Don used to cover his face to reveal the face of Baba, their father and husband, to their utter disbelief and shock.

Little Drops portrays the hellish condition of war between the government Joint Task Force and the militants and its terrifying effect on the civilian population, especially children and women. In the play, the militants had blown up the refinery and kidnapped the white oil workers, forcing the soldiers to rampage through the area, raping women, burning down houses and even sacred places, maiming and killing anybody they see. The militants, apart from attacking the soldiers, oil installations and workers, equally target dubious leaders who connive with government officials 
to wreck the people. The King who is accused of playing double standards has just been killed and decapitated and a bullet pierces the back of his little child while his wife Azue flees the scene of the horrible scene. In the text Memekize who now lives alone at the riverbank among the tombs of her husband and two sons dismembered by shelling during the Biafran war becomes the rallying point for the women like Mukume, Bonuwo and Azue who are running away from the terrorizing soldiers and the militants. Memekize's shanty place is not even a safe haven as sounds of shelling frequently disrupt their activities and escaping militants with bullet wound like Kuru run into the place and threaten the women with firearms. Also, in the play a school building has been bombed and all the children in it were killed and mangled. The play suggests that the war becomes directionless by the day because of the proliferation of the militant groups and leaders with different motives.

The third play, Ipomu is a medley of man-made and supernatural issues. The first picture painted by the play is that of a degraded and deracinated environment. The river is polluted by oil spillage and this left all the aquatic lives in it dead, producing revolting stench. Secondly, Ebiere the first wife of the King complains of loveless life as she has been abandoned by the King for younger women because he has come in touch with oil money. Thirdly, there is the issue of mistrust among the militants, which makes them to dupe and haunt one another. On the supernatural angle, Ipomu is requested to bring down his father's calabash of life, which hangs his life in the balance, causing him to dangle between life and death. The King suffered stroke during the night he was preparing for a sexual encounter with Bikiya his newly married virgin. Eventually, the King died and Bikiya and Ipomu whose body languages suggest that they are made for each other, thus consummate their love in a royal marriage.

\section{Textual analysis and interpretation}

The first and most disturbing set of antimony in the Niger Delta, which Ahmed captures vividly in his trilogy, is the issue of affluence versus affliction. The text demonstrates that social and economic progress exist for only a select few oil magnets, their proxies and cronies while the majority live in filth and abject poverty. In the Hard Ground Nimi tells his mother that God did not "create all those sufferings. No, God created a fine life for us Mama, but a few people say no, we must live a hard life" (15). Ibeanu observes that "what is happening in the Niger Delta is a clear lesson of the dialectical relation between affluence and affliction and how different social forces try to reconcile the two" (2008: 15). Oil has been a source of wealth for the multinational oil companies, government officials, security agencies, criminals that engage in oil bunkering, various militant groups and traditional rulers who collaborate with the government to ensure stagnation of social welfare improvement of the people. Oil is the major source of Nigeria's revenue and the government officials and petro bourgeoisie who are in control of political power and oil wealth indulge in a life of profligacy. In Hard Ground, Nimi in reference to the lifestyle of white oil workers states that, "they dress in fine clothes at weekends in the cities after exploiting our oil, dancing to town in their helicopters and jeeps, to exploit our women and girls" (39). The implication is that the petro bourgeoisie use their affluence to intimidate the natives and buy the love of their women. Young ladies flock to oil rich men while married women frequently desert their husbands to rumble on the laps of oil moguls. Oil money as Igege a character in Ipomu would say "has 
brought traffic jam everywhere" (128). It breeds mistrust among family members; between government officials and the militants, and between traditional rulers and their subjects. In Ipomu Queen Ebiere laments that her husband who once cherished her when he was a poor boat maker, has abandoned her now that he is King and has come in touch with oil money. Aroused by the mating songs of bullfrogs, she complains to her son Ipomu:

What do I know anymore? When last did I hear the grunt of love or that of a man? When has your father looked at me as something but a framed doll fit only to carry his beaded crown at the New Year festival. Now it is my twilight and I long for that grunt. (13)

Whereas Ebiere who has now become a ceremonial wife, toss and twirl in bed, her husband the King, sucks and tickles the breasts of younger women in his palace built with oil money. In Hard Ground, Yerima projects the complexity of the variables fanning the embers of crisis through the activities of shrewd capitalists like Inyingifaa who traffics in illegal guns which is a major factor in the proliferation of militant camps and the consequent turmoil and atrocities. Inyingifaa's sister Mama considers him a traitor who "measures everything in terms of money" and will sell his own blood if the price is good (33). In the same text, Nimi is praised by their leaders for helping to eliminate Chief Tamford who, as a middle man between his people and the government, indulge in self-aggrandizement. Tonye avers that Tamford has an army of his own comprising young children whom he used to gain undue advantage while his own children are sent abroad for good education and decent living. In Little Drops the Janus-faced King was killed by a militant group for betraying the community before the government officials, sending his three wives home for 'smelling of old age', and for buying the love of their leader's wife. The supposition here is that the way and manner devious oil deals and transactions in the Niger Delta generate affluence is what indeed leads to chocking mistrust and betrayal; no one is sure of anybody, including family members.

On the other hand, oil extraction and production in the Niger Delta daily generate untold environmental affliction and unimaginable hardship and poverty for the people. In an article entitled, 'Challenging Impediments to Climate Change Initiatives in Greg Mbajiorgu's Wake up Everyone', Norbert Oyibo Eze observes that the discovery of oil in commercial quantities in the Niger Delta, "led to the scrambling for the area by the capitalist multinational oil drilling and marketing companies" (2018: 274). In his highly perceptive article entitled, 'A Journey of a Thousand Miles: Researching Conflicts in the Niger Delta' Cyril Obi avers that, "running under villages, waters, mangrove forests, farms and sacred places are pipes like veins from which oil and gas are pumped daily, feeding the growing almost insatiable appetite of the developed and more prosperous world" (2008: 12). The capitalist greedy exploitation of oil does not in any way spare the Niger Delta; humans, animals especially fishes, land and water are altogether abysmally affected. Elaborating on the terrible condition under which the Niger Deltans live due to the adverse effects of unwholesome process of oil exploitation, Ibeanu states that:

Pollution arising from oil spillage destroys marine life and crops, makes water unsuitable for fishing and renders many hectares of farming land unusable. Brine from oil fields contaminates water formations and streams, making them unfit as sources of drinking water. At the same time flaring of gas in the vicinity of human dwelling and high pressure of oil pipelines that form a mesh across farmlands are conducive to acid rains, deforestation and destruction of wildlife. In addition, dumping 
of toxic, non-bio degradable by-products of oil refining is dangerous to both flora and fauna, including man. (2008: 18)

This implies that rural livelihoods are under intense pressure and that existence in this area is quite precarious as all forms of life, atmosphere and the environment gasp for breath. Life is a nightmare where it is extremely difficult to breathe fresh air, find uncontaminated food and drinking water. Yerima harps on the affliction the people suffer in Ipomu where the major character in the play, Ipomu describes their journey home to his mother, Ebiere:

Ebiere: I am happy you came home son. You look rested now. Last night, you were a frightened sight to behold. Tired and spent.

Ipomu: Like a log mama, a soaked up, swollen water log. Damp and heavy. Dirt like scales on my body. Leeches stuck to my boots, praying they should turn into my feet skin. We walked in the oily stained river; the oil river mixed with shreds, carcasses of dead fish... and burnt crayfish half fried with the river oil and the basking heat from the sun. Oh! The sickening smell... revolting stench. (121)

In Hard Ground, Nimi makes reference to "the black oily soil" (11), "deadly Swamp" and "murky water" (15), which impair farming and fishing that were the people's sources of livelihood before the discovery of oil. He tells his mother plainly that theirs is a wasteland that promotes poverty. He insists that "poverty stinks" and that, "if another man holds the soap and won't let you have it, then nudge him slightly. For you need a good bath to become a decent perfumed human being like him" (12). This is his reason for joining the militant camp.

In Ipomu, the character Ipomu maintains that, "a hungry man, scared and unsure when death will come does not sleep" (131). The extremely poor living condition of the masses is epitomized by Memekize's shanty dwelling at the riverbank in the Little Drops. This woman who feeds only on roasted water yam and illicit gin is not even safe and has not experienced peace in her poor dwelling place as sounds of shelling and escapees from the battle between the soldiers and the militants harass her every now and again. This is in addition to the psychological trauma she lives with as a result of the loss of all her children and husband during the Nigeria-Biafra war.

The paradox of affluence and affliction is ignited by the antimonies of development and underdevelopment that characterize crude oil production in the Niger Delta. According to Ibeanu "one of the most glaring contradictions in the Niger Delta is the glaring difference between the petro bourgeoisie and the proletariat. Indeed a lasting paradox of the petro-state in Nigeria is the level of poverty in the Niger Delta, which is the source of the country's wealth" (2008: 18). While electricity, clean pipe borne water, quality healthcare and schools and good roads are provided in oil installations and the residences of oil workers in cities like Port Harcourt and Yenegoa, for example, the masses are left floundering in murky environment degraded by oil spillage, gas flaring and non-biodegradable effluents from the refineries, with poor and nigh absence of infrastructural facilities. Nimi complains to Mama in the Hard Ground that, "the school you sent me to was made up of wasteland and poverty" (13). Ipomu suggests that transportation is mostly by canoes through murky stinking oil water frequently rendered non-navigable by water hyacinth. This is the reason Port Harcourt the Garden city and Yenegoa are posited in the trilogy as an Arcadia, a sort of Eldorado where in Little Drops, women are said to float in "pleasure with white oil diggers" (80); and as the play comes to an end, everyone except Memekize's paddles to Port- 
Harcourt. In Ipomu, Ebiere talks about Yenegoa having "tall building"... "brightly coloured houses", "wide and well lit roads", and "huge roundabouts" (128). Of course, this contrasts with the creeks and their odious environment.

Again, Ibeanu posits that, "in the Niger Delta, national security contradicts the security of the' Niger Delta people, 'because of the politics of oil" (2008: 20). It is pertinent to note that the military invasion of Nigerian politics has made it a major contender of political power and economic structure. Top military officials during the era of military dictatorship acquire oil blocks and liaise with foreign oil investors to indulge in primitive acquisition of Nigerian oil wealth. For this group, national security means aggressive and uninterruptible production of crude oil, and this is pursued irrespective of unwarranted ecological damages and their consequent negative impacts on the people's livelihood. In fact, in order to quell protests and social uprisings, the state instead of employing dialogue and discussion adopts violence. Ibeanu argues that "state aggression against the people of Niger Delta has taken four main forms namely, constant harassment of the leaders of popular movement and organizations, instigating inter-communal conflicts, especially along ethnic, religious and clan lines, instigating internal division of popular organizations and direct repression using the army and police" (2008: 25).

However, people feel insecure and bitter whenever their means of subsistence are threatened and the ensuing anxiety frequently leads to protests, even violent ones. Ibeanu observes that, "on the part of the local people in the Niger Delta and their organizations, the condition for security is the maintenance of the carrying capacity of the environment" (2008: 24). The people recognize that "an unsustainable exploitation of crude oil, with its devastation of farmlands and fishing waters threatens resource flow and livelihoods" (Ibeanu, 2008: 24). And because the demands for alternative means of cushioning, the effects of oil spillage and the hardships they bring along are not met by the oil investors, embittered youths vent their anger against oil investments.

Yerima's trilogy depicts that the people's strategies of pressing home their demands include hijacking of oil installations, kidnapping of oil workers, especially white men, vandalization of oil pipelines and outright push for resource control. As the play, Hard Ground opens the character Nimi has just been rescued from being killed by the government forces because of the kidnapping of four white men by his militant group. In that retaliatory action, Nimi's camp lost twenty people and while Nimi accuses Fr. Kingsley whom he confesses their activities to, Baba tells us that Nimi's name "was on every set of lips" (12) as the one who leaked the exercise to the police. The idea of betrayal harped upon here suggests as Inyingifaa would say that, "the swampy forest could not hold a secret any longer" (24) and that "the air of mistrust is choking" as nobody can be trusted anymore, including the chiefs because "too much money was passing from one hand to another" (24), making it difficult for any meaningful achievement to be recorded. In fact, oil politics has created intricate and untrustworthy relationships. When Inyingifaa informs Nimi that the police spy has been caught and subjected to a gruesome death along with her unborn child since a vulture will always beget her kind, he exclaims, "Good. The cause of the land is greater than us" (52); but when he realizes that the victims were his wife Pikibo and her unborn child, he screams:

Noo! Not Pikibo! No! Not my son! He did not offend a soul. The Don should have spared their lives for my sake. I must find the Don and kill him too. (52) 
However, when the Don is finally killed by Nimi during a scheduled visit, both Nimi and Mama discover to their disbelief that the man who had caused the family so much pain was Baba. In the Little Drops mistrust and crises assume a more horrendous dimension leading to more deaths and population displacement. State violence has been unleashed against people because the militants blew up the refinery and kidnapped white oil workers. In the complex and monstrous battle, both the government forces (JTF) and the militants bombard and rampage through the area like characters in the Homeric battlefield, demonstrating, according to Northrop Frye, "the greatest possible power of action" (134) by raping women, raising down civilian houses, including sacred places, killing and maiming both innocent and perceived offenders. The first segment of Little Drops portrays women and children as the most negatively affected population. As the play opens, Mukume rushes into Memekize's dwelling place; she is running away from the militants who gangraped her while she was having a honeymoon with her newly married husband, Ovievie in a hotel. As Memekize is trying to console and attend to her, Azue the Queen appears, very exhausted from running and with a child straddled at her back. Her husband the King has just been killed and decapitated by a militant group in front of his family for collecting "bags of money" (78) from the government. As the women take the child from her mother to clean up and feed, it is discovered that a bullet had pierced her fragile back and lodged in his small stomach, causing the Prince's life to be ended "before it began" (86). As the women are trying to come to terms with the untimely death of the young child, another woman Bonuwo runs in, very unkempt. She is escaping being lynched by angry parents whose children she left in the class to ease herself were all dismembered and mangled by shelling. Bonuwo recounts the ugly story:

I ran out when I heard screams and shouts. First it was like a dream. The roof of my classroom was blown open. Huge smoke and heavy smell of charred skin and burnt flesh. Not one soul...not one child was spared. All I saw were cut off limbs, little trunks, cut off heads, with their hair still burning...Ayiba...forty-one of them all dead. And when the parents came and met me alive, they took stones, shoes and other sharp objects they could lay their hands on, and chased me out of town. (93)

The above tends to support the claim that the crisis in the Niger Delta is hydra headed, enormous and complicated, a case of survival of the fittest, which reminds one of the Hobbesian state of nature, where man is a wolf unto his kind. The issue of money and how it is handled in the area appears to muddle up things. The plays demonstrate that efforts to make things work are sabotaged as a result of self-aggrandizement. Adeyemi Adegoju and Esther $\mathrm{C}$. Anyanwu argue that in the idiom of the play, money "becomes a commodity for fuelling the crisis in Niger Delta" (2017: 497). The Chiefs in the plays accept money from the government and the multinationals to betray their conscience and sense of duty to the people and this compels them to speak with two sides of the mouth. Referring to her husband's attitude in the Little Drops, Azue warns: "A King cannot be King in the morning and a spy at night. You will have your crown tripped off" (81).

Christine Odi posits that the killing of the King by his own subjects signifies loss of confidence and trust in the traditional institution (2017: 380). The Kings who are the custodians of culture and moral conscience of the society have become loathsome vultures in the eyes of their subjects because they allow oil money to rubbish their dignity and the institution reserved for honourable and truthful people thereby disrupting their cohesive role as the symbol of traditional authority. The King's unacceptable disposition in Little Drops which eventually leads to his gruesome death and the burning down of his palace is equally found among the militants. Many 
receive money from oil investors and the government to encourage splitter militant groups as a means of exacerbating rivalry to dissipate genuine struggle. Kuru, a militant in Little Drops refers to the proliferation of the militant groups when he tells Memekize:

Yes, but it will not be easy, but I will try to speak with the leaders. The only problem is that the leaders are now very many, but if I live, then I can talk to the ones I find (113).

The question of mistrust in handling money is exemplified by Ovievie who escaped with his gang's money to marry and enjoy a honeymoon. It is amplified in Ipomu where Igege and Ipomu discuss their role in the amnesty and the money involved, which their leader called the Crab seems to disappear with. Hear an abridged conversation between the two:

Ipomu: ...I say where is my money?

Igege: I don't know. But they say the Crab will give us...

Ipomu: And the leader did not say where he was?

Igege: No, But...

Ipomu: He tells us to surrender...we do, they promise us money...and he goes back to plan an offensive without his field boys. What does he want? More money? I will kill someone with my bare hands if I discover I was cheated (132).

The dialogue suggests that the crisis in the Niger Delta instead of abating, appears to be compounding daily not only because of the selfish interest of the petro bourgeoisie but also because of the self-seeking disposition of the community leaders, organizations and various militant groups. The implication is that development and underdevelopment, national security and insecurity of the Niger Delta people, as well as affluence and affliction may continue to exist in a region whose resources make Nigeria a mono economy.

However, in the last play of the trilogy Ipomu, the playwright through the mythic instrument of 'the calabash of life' (142) suggests a change of the old order noted for its destruction of lives to a new one driven by love and protection of life. Of course, the emergence of the new order exemplified by the consummation of the marriage between Bikiya and Ipomu compels the new King to tell Preye who requests to be killed for not meeting up with the agreed time for their journey to the city that, "death and I have just parted ways" (165).

\section{Conclusion}

This paper examines Ahmed Yerima's trilogy, which is the playwright's attempt to clarify and sensitize people (Nigerians and non-Nigerians) on the contradictions and horrendous agonies that accompany crude oil exploration and extraction in the Niger Delta acclaimed to be the most significant wetland in Africa. The study adopts the antimonies of crude oil production espoused by Okechukwu Ibeanu in his inaugural lecture as its conceptual inclination for analysis. Hard Ground, Little Drops and Ipomu, which compose the trilogy, were examined to demonstrate how they embody the antimonies of affluence and affliction; development and underdevelopment, and national security versus the insecurity of the Niger Delta people. Our analysis indicates that social progress exists for the oil investors, government officials and a few sons of the land especially the traditional rulers who use the oil money to enjoy decent, even profligate existence while for the 
masses, life is a nightmare owing to oil spillage, gas flaring and effluents from refineries, which have continued to degrade the environment and put pressure on means of livelihood. Lack of alternative means of cushioning the effects of environmental despoliation makes the people to feel threatened and uncontrollable anxiety leads to outburst of emotion in form of protests, vandalization of pipelines, kidnapping of oil workers especially white men.

On the part of the government and the multinationals, the activities of the militants must be checked because as an oil-dependent country any disruption of oil production will lead to financial crisis. This understanding compels the government to deploy state violence, and the army and police because of their poor training, usually behave like characters in the Homeric battlefield in their display of possible action. The brutish action of the government instead of ameliorating the crisis exacerbate it because it constrains the various militant groups to arm themselves with heavy weapons to match the government forces, which they sometimes overwhelm. Our study shows that in all this, the civilians especially women and children are caught in the crossfire and while some are killed, others are maimed and very many displaced.

\section{References}

Achebe, C. 1983. An image of Africa and the Trouble with Nigeria. New York: Penguin Books.

Adegoju, A. \& Anyanwu, E. C. 2017. 'A stylistic criticism of Niger Delta conflict rhetoric in Ahmed Yerima's Hard Ground. Paradigms of modern Nigerian drama. Ed. A. A. Akpuda. Owerri: Chimbest Global \& Amitext Graphics Services.

Aniago, E. 2017. Polemics of Nigeria's socio-political realities and Chinua Achebe's The Trouble with Nigeria' Rupkatha Journal on Interdisciplinary Studies in Humanities 9(4): 25 - 36.

Dike, K. 1974. 'Trade and politics in the Niger Delta' In: The making of Black America vol. ii. Eds. A. Meier and E. Rudwick. New York: Athenuem.

Enekwe, O. O. 1990. 'Rich land, poor people: One view of underdevelopment'. The Making of the Modern World: A History of the Twentieth Century. Dubuque-Iowa: Kendall Hunt Publishing Company.

Eze, N. O. 2018. 'Challenging impediments to climate change initiatives in Greg Mbajiorgu's Wake up Everyone'. In: The Environmental Crunch in Africa. J. Abbink (ed) Cham-Switzerland: Palgrave Macmillan.

Frye, N. 1973. Anatomy of Criticism. New Jersey: Princeton University Press.

Gurr, T. R. 1970. Why Men Rebel. New Jersey: Princeton University Press.

Ibeanu, O. 2008. Affluence and Affliction: The Niger Delta as a Critique of Political Science in Nigeria. Nsukka: University of Nigeria Press.

Neil, M. 1989. 'Unpopular beds: Race, adultery and the hideous in Othello'. Shakespeare Quarterly, 40(4): $383-412$.

Obi, C. 2008. A journey of a thousand miles: Researching conflict in the Niger Delta'. Africa in Search of Alternatives. Annual Report. Uppsala: Nordic Africa institutet.

Odi, C. 2017. 'Ebiaba Irobi, Ahmed Yerima, Uwemedimo Atakpo and the Niger Delta struggle'. Paradigms of Modern Nigerian Drama. A. A. Akpuda (ed) Owerri: Chimbest Global. 
Ogbeidi, M. 2012. 'Political leadership and corruption in Nigeria since 1960: A socio-economic analysis'. Journal of Nigeria Studies, 1(2): 1 - 25.

Ota, O. O. 2017. Postcolonial Niger Delta in Nigerian drama: Internal colonization/A house divided?' In: Paradigms of Modern Nigeria Drama. A. A. Akpuda (ed) Owerri: Chimbest Global \& Amitex Graphics Services.

Pattanaik, S. 2008. 'Oman's monetary policy transmission process under the fixed Peg: Some empirical puzzles'. Macroeconomics and finance in Emerging Market Economies, 1(2): 181 - 198.

Reade, W. 1974. cited in Kenneth Dike's 'Trade and politics in the Niger Delta'. The Making of Black America. A. Meier and E. Rudwick (eds). New York: Atheneum.

Tänzler, D., Maras, K., Giannakopoulos, A., \& Ralf, R. 2012. 'The social construction of corruption: Theoretical reflection' In: The Social Construction of Corruption in Europe, Tänzler, D., Maras, K., \& Giannakopoulos, A. (eds), Surrey: Ashgate Publishing Limited, 13 - 29.

Yerima, A. 2011. Three Plays. Ibadan: Kraft. 